\title{
The Diagnosis and Management of Hyperinsulinaemic Hypoglycaemia
}

\author{
Klára Roženková1,2, Maria Güemes2,3, Pratik Shah2,3, Khalid Hussain2,3 \\ ${ }^{1}$ Charles University in Prague and University Motol Hospital, Department of Paediatrics, Prague, Czech Republic \\ 2University College London, Institute of Child Health, Genetics and Epigenetics in Health and Disease, \\ Genetics and Genomic Medicine Programme, London, UK \\ 3 Great Ormond Street Hospital for Children NHS Trust, Department of Paediatric Endocrinology, London, UK
}

\begin{abstract}
Insulin secretion from pancreatic $\beta$-cells is tightly regulated to keep fasting blood glucose concentrations within the normal range $(3.5-5.5 \mathrm{mmol} / \mathrm{L})$. Hyperinsulinaemic hypoglycaemia $(\mathrm{HH})$ is a heterozygous condition in which insulin secretion becomes unregulated and its production persists despite low blood glucose levels. It is the most common cause of severe and persistent hypoglycaemia in neonates and children. The most severe and permanent forms are due to congenital hyperinsulinism (CH). Recent advances in genetics have linked $\mathrm{CHI}$ to mutations in 9 genes that play a key role in regulating insulin secretion $A A B C C 8, K C N J 11, G L U D 1, G C K, H A D H$, SLC16A1, UCP2, HNF4A and HNF1A). Histologically, CHI can be divided into 3 types; diffuse, focal and atypical. Given the biochemical nature of $\mathrm{HH}$ (nonketotic), a delay in the diagnosis and management can result in irreversible brain damage. Therefore, it is essential to diagnose and treat $\mathrm{HH}$ promptly. Advances in molecular genetics, imaging methods (18F-DOPA PET-CT), medical therapy and surgical approach (laparoscopic surgery) have completely changed the management and improved the outcome of these children. This review provides an overview of the genetic and molecular mechanisms leading to development of $\mathrm{HH}$ in children. The article summarizes the current diagnostic methods and management strategies for the different types of $\mathrm{CHI}$. Key words: Congenital hyperinsulinism, hypoglycaemia, 18Fluorine-Ldihydroxyphenylalanine positron emission tomography scan, diazoxide, pancreatectomy, sirolimus
\end{abstract}

Conflict of interest: None declared

Received: 16.01 .2015

Accepted: 20.02 .2015

\section{Introduction}

Hyperinsulinaemic hypoglycaemia $(\mathrm{HH})$, one of the most frequent causes of persistent hypoglycaemia in neonates and infants, is a heterogeneous condition caused by dysregulation of insulin secretion from pancreatic $\beta$-cells. It is extremely vital to make a rapid diagnosis of $\mathrm{HH}$ and institute immediate appropriate management in these patients to prevent hypoglycaemic-related brain injury resulting in neurological complications like cerebral palsy, epilepsy and even death (1). The increased risk of brain injury in $\mathrm{HH}$ is due to the metabolic actions of insulin driving glucose into the insulin-sensitive tissues (skeletal muscle and adipose tissue) and inhibiting the glucose production via glycolysis and gluconeogenesis. Insulin also inhibits fatty acid release and ketone body synthesis; hence, the brain is deprived of both its primary and secondary energy sources (glucose and ketone bodies) (2). In addition to ketone bodies, lactate also provides an alternative cerebral fuel in hypoglycaemic newborns (3).

The most severe forms of $\mathrm{HH}$ are inherited and the term congenital hyperinsulinism (CHI) refers to these inherited forms of $\mathrm{HH}$. However, $\mathrm{HH}$ can also be secondary to various risk factors like perinatal asphyxia, maternal diabetes mellitus, intrauterine growth restriction (4), or associated with syndromes affecting growth like Beckwith-Wiedemann syndrome (BWS) and Sotos syndrome (5).

$\mathrm{HH}$ typically presents as fasting hypoglycaemia, but in some cases, the hypoglycaemia is provoked by protein/leucine loading or even exercise. Insulinoma, although a rare cause, should be considered in older children and adolescents presenting 
with recurrent hypoglycaemia. The clinical presentation is heterogeneous, patients can be completely asymptomatic, have a pharmacologically responsive mild disease or a severe disease un-responsive to medication needing surgical intervention (6).

$\mathrm{CHI}$ occurs due to mutations in key genes which play a role in insulin secretion from pancreatic $\beta$-cells. Currently mutations have been identified in nine different genes (ABCC8, KCNJ11, GLUD1, GCK, HADH, SLC16A1, UCP2, HNF4A and HNF1A) that lead to dysregulated secretion of insulin $(5,7,8)$. The most common cause for $\mathrm{CHI}$ are mutations in the genes $\mathrm{ABCC} 8$ and KCNJ11 (both autosomal recessive and dominant) that encode the SUR1 and Kir6.2 subunits of the pancreatic $\beta$-cell $K_{\text {ATP }}$ channel, respectively $(9,10,11,12,13,14)$. The genetic defects associated with $\mathrm{CH}$ are summarized in Figure 1.

Histologically, $\mathrm{CHI}$ is classified into three subgroups: diffuse, focal and atypical forms $(15,16)$. In the diffuse disease, there are hyper-functioning pancreatic $\beta$-cells affecting the whole pancreas. Children with diffuse form of $\mathrm{CHI}$ due to recessive mutations in $A B C C 8$ and KCNJ11 usually do not respond to diazoxide. Focal forms are sporadic in inheritance and associated with a paternally inherited mutation in ABCC8/ KCNJ11 genes $(17,18,19)$. Focal lesion may occur in any part of the pancreas, although the tail and body are the most common locations $(20,21)$. Histologically, focal forms are characterised by nodular hyperplasia of islet cell and ductuloinsular complexes surrounded by histologically and functionally normal pancreatic tissue (22). In the "atypical" forms, there is an enlargement of pancreatic $\beta$-cell nuclei that is confined to discrete regions of the pancreas (23). This histological picture raises the possibility of mosaicism $(24,25)$. An ABCC8 mutation and mosaic uniparental disomy has been reported to cause atypical form of $\mathrm{CHI}$ (25).

\section{Causes of HH}

\section{Transient HH}

Transient $\mathrm{HH}$ spontaneously resolves within a few days to up to a few months (26). It is usually secondary to maternal diabetes mellitus, intra-uterine growth restriction, perinatal asphyxia, polycythaemia, maternal administration of drugs such as sulphonylureas and intravenous glucose infusions during labour (9).

\section{Congenital Hyperinsulinism (CHI)}

\section{(a) Pancreatic $\beta$-cell $K_{\text {ATP }}$ channel defects}

Mutations in genes ABCC8 (SUR1 subunit) and KCNJ11 (Kir6.2 subunit) are the most common cause of $\mathrm{CHI}$. Both the ABCC8/KCNJ11 genes are localized on chromosome 11p15.1. The most severe forms of $\mathrm{CHI}$ are due to recessive inactivating (loss of function) mutations in ABCC8 and KCNJ11 leading to unregulated insulin secretion despite severe hypoglycaemia $(10,11)$. Dominant inactivating mutations in ABCC8 and KCNJ11 usually cause a milder form of $\mathrm{CHI}$ which is responsive to diazoxide $(17,27)$. However, medically unresponsive forms have also been reported (28).

\section{(b) Hyperinsulinism/hyperammonaemia syndrome (HI/HA)}

Dominant missense mutations in the gene GLUD1, which encodes mitochondrial enzyme glutamate dehydrogenase $(\mathrm{GDH})$ (29), cause $\mathrm{HI} / \mathrm{HA}$. As a result, the GDH activity is increased and that leads to inappropriate insulin secretion from pancreatic $\beta$-cells and excessive ammonia production. However, there is a rare group of patients who demonstrate leucine hypersensitivity but have a persistently normal serum ammonia level $(15,30)$. Children usually have milder symptoms compared to other forms of $\mathrm{CHI}(15,30)$. Urinary $\alpha$-ketoglutarate excretion is raised in HI/HA patients (31).

\section{(c) Glucokinase gene mutations}

Glucose is phosphorylated to glucose-6-phosphate by the enzyme glucokinase (GCK) that helps to control glucose metabolism in the $\beta$-cell (32). Mutations in GCK lead to increased ATP: ADP ratio in the pancreatic $\beta$-cell. This then results in K KTP channel closure and inappropriate secretion of insulin (33). The activating GCK mutations are inherited in an autosomal dominant manner with varying severity of symptoms within the families and generally respond to diazoxide $(34,35)$.

\section{(d) HADH gene mutations}

Mitochondrial L-3-hydroxyacyl-coenzyme A dehydrogenase (HADH) gene on chromosome 4q22-26 (36) encodes the enzyme HADH. Mutations in this gene are a rare cause of $\mathrm{CHI}$ (37). This enzyme activity is high in the pancreatic $\beta$-cells, where it converts L3-hydroxyacyl CoA to 3-ketoacyl CoA and then subsequently to 3-hydroxybutyryl-CoA, the penultimate step of the $\beta$-oxidation pathway. $H A D H$ gene mutations can lead either to severe neonatal $\mathrm{CHI}$ or to mild late-onset $\mathrm{CHI}$ (38). Some but not all patients with $H A D H$ mutations have abnormal organic acid profiles and acylcarnitines $(15,30)$. So far, there has been no report of diazoxide-unresponsive hyperinsulinism in this group (39).

\section{(e) Exercise-induced hyperinsulinism (SLC16A1)}

SLC16A1 gene encodes monocarboxylate transporter 1 (MCT1) which is required for transport of pyruvate and lactate into pancreatic $\beta$-cells. Activating mutations in SLC16A1 increase the expression of MCT1 in the $\beta$-cells, which under normal conditions is very low. Strenuous exercise then leads to accumulation of lactate and pyruvate which results in pyruvatestimulated insulin secretion (40). Medical treatment is usually not required and hypoglycaemic episodes can be prevented by avoiding strenuous exercise $(41,42)$.

\section{(f) UCP2 gene mutations}

Uncoupling protein 2 (UCP2) disengages oxidative metabolism from ATP synthesis in the pancreatic $\beta$-cell. Mutations in UCP2 gene increase ATP synthesis and glucosesensitive insulin secretion leading to $\mathrm{HH}$ (43).

\section{(g) HNF4A and HNF1A gene mutations}

Hepatocyte nuclear factor $4 \alpha$ (HNF4A) gene encodes for the transcription factor $\mathrm{HNF} 4 \alpha$, a nuclear hormone receptor involved 
in glucose-stimulated insulin secretion (44). Heterozygous mutations in the HNF4A gene have been reported to cause transient $\mathrm{CHI}$ in the newborn period $(45,46)$ and maturityonset diabetes of the young type 1 due to progressive $\beta$-cell dysfunction (47) in adolescence or early adulthood. Affected patients are usually born large for gestational age (LGA) and present with $\mathrm{HH}$ within the first week of life, which is responsive to diazoxide (48).

Recently, missense mutations in the HNF1A gene have been described to cause transient $\mathrm{CHI}$. The clinical definition is not complete, but the phenotype is similar to the HNF4A mutations and these children may well be responsive to diazoxide $(49,50)$.

\section{Postprandial forms of $\mathrm{HH}$}

Postprandial $\mathrm{HH}(\mathrm{PPHH})$ is a condition that causes hypoglycaemia within a few hours of meal ingestion due to inappropriate insulin secretion in response to the meal. "Dumping syndrome" is a type of PPHH in children who have undergone Nissen's fundoplication/gastric bypass surgery $(51,52)$. PPHH after Nissen's fundoplication has an abnormally excessive secretion of glucagon-like peptide-1 (GLP1) which may lead to exaggerated insulin secretion resulting in hypoglycaemia (53).

$\mathrm{PPHH}$ can also be caused by an autoimmune condition in which there is presence of insulin-binding autoantibodies in children who have not been previously exposed to exogenous insulin (54). PPHH has also been reported in some cases of insulin receptor gene mutations (leprechaunism) $(55,56)$.

\section{Other causes of HH}

Insulinoma, a rare form of neuroendocrine tumor, must be considered in older children or adolescents presenting with $\mathrm{HH}$ (57). Family history is extremely important as a diagnostic clue in familial cases where insulinoma may be a part of multiple endocrine neoplasia syndrome type 1 .

\section{Clinical Presentation of $\mathrm{HH}$}

$\mathrm{HH}$ most commonly presents during the neonatal period. Although less frequently, $\mathrm{HH}$ can also manifest later in infancy, childhood or exceptionally in adolescence or adulthood, but usually with a milder phenotype.

The clinical symptoms of hypoglycaemia are nonspecific in the neonatal period and can include poor feeding, hypothermia, irritability, lethargy, apnoea, seizures and even coma. Symptoms generally develop after a period of fasting or when the child is unwell. In some forms of $\mathrm{HH}$, the episodes of hypoglycaemia can be triggered by protein-rich meals (in HI/HA syndrome (and in $\mathrm{HADH}$ gene mutations), exertion [exercise-induced $\mathrm{HI}$ $(E I H I)](26)$ or postprandially [in dumping syndrome and insulin receptor gene mutations (58)].

Many developmental syndromes may be associated with $\mathrm{HH}$ (59). BWS is the most commonly associated as $50 \%$ of these children will present with $\mathrm{HH}(60)$. In the majority of

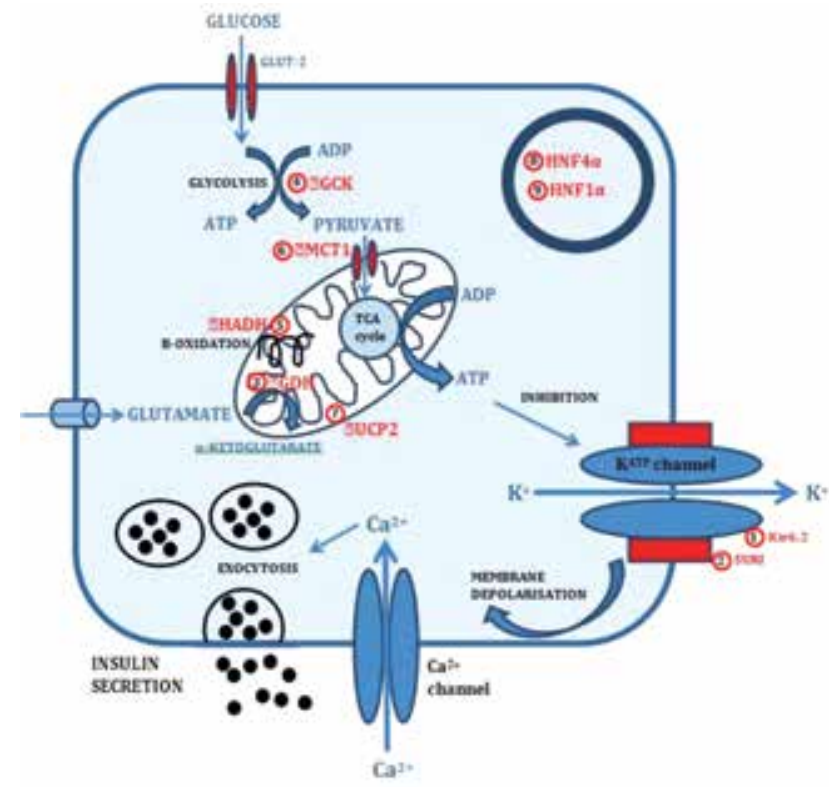

Figure 1. Genetic defects associated with $\mathrm{CHI}$ : (1) SUR1 subunit of the $\mathrm{K}_{\text {ATP }}$ channel encoded by $A B C C 8$ gene; (2) Kir6.2 subunit of the $K_{\text {ATP }}$ channel encoded by KCNJ11 gene; (3) Glutamate dehydrogenase (GDH) encoded by GLUD1 gene; (4) Glucokinase (GCK) encoded by GCK gene; (5) L-3-hydroxyacyl-coenzyme A dehydrogenase (HADH) encoded by HADH gene; (6) Monocarboxylate transporter (MCT1) encoded by SLC16A1 gene; (7) Uncoupling protein 2 (UCP2) encoded by UCP2 gene; (8) Hepatocyte nuclear factor $4 \alpha$ (HNF4 $\alpha$ ) encoded by HNF4A gene; (9) Hepatocyte nuclear factor $1 \alpha$ (HNF1 $\alpha$ ) encoded by HNF1A gene

BWS, HH will be transient to a few days, but in $5 \%$ of them, it will be permanent requiring medical therapy and in some cases - subtotal pancreatectomy (60). Other syndromes where $\mathrm{HH}$ has been described are those with: overgrowth [Sotos (61), Simpson-Golabi-Behmel (62)], growth failure [Kabuki (63), Costello (64)], chromosomal abnormalities [trisomy 13 (65), mosaic Turner (66), insulin receptor mutation (leprechaunism) $(67,68)$ and others congenital disorders of glycosylation $(69,70,71)$, congenital central hypoventilation syndrome] (72).

\section{Diagnosis of $\mathrm{HH}$}

The history should focus on identifying risk factors for $\mathrm{HH}_{\text {; }}$ these include the presence of: maternal diabetes mellitus (pre and gestational), intra-partum drugs administered to the mother (glucose infusions, oral hypoglycaemic agents), eventful delivery (foetal distress, birth asphyxia), prematurity, small for gestational age (SGA) and LGA. When taking the family history, it is important to identify other family members with episodes of hypoglycaemia - possibly misdiagnosed as infantile seizures or unexplained deaths (58), but also diabetes mellitus and its onset age and the existence of consanguinity.

In the physical examination, special attention should be paid to auxology (macrosomia and SGA are more 
common in transient $\mathrm{HH}$ ) and syndromic features to rule out developmental syndromes. BWS will typically manifest with macroglossia, hemihypertrophy, anterior abdominal wall defects, organomegaly, ear lobe creases, helical pits and renal tract abnormalities. The presence of hepatomegaly in patients with $\mathrm{HH}$ indicates the excessive glycogen deposition, but may also redirect the diagnosis towards metabolic conditions (e.g. glycogen storage disorders) and findings such as midline brain

\begin{tabular}{|l|l|l|}
\hline Table 1. Biochemical findings in hyperinsulinemic hypoglycaemia (HH) & Result \\
\hline & Hormone/metabolite measured in serum & Low \\
\hline \multirow{5}{*}{ Biochemical findings in all types of HH } & Glucose & Detectable/raised \\
\cline { 2 - 3 } & Insulin & Detectable/raised \\
\cline { 2 - 3 } & C-Peptide & Suppressed/low \\
\cline { 2 - 3 } & Beta-hydroxybutyrate & Suppressed/low \\
\cline { 2 - 3 } & Free fatty acids & Suppressed/low \\
\cline { 2 - 3 } & IGFBP-1 & Normal \\
\cline { 2 - 3 } & Cortisol, growth hormone, amino acids and urine organic acids & Raised \\
\hline HADH deficiency subtype & Hydroxyl-butyrylcarnitine & Raised/normal \\
\hline HI/HA subtype & Ammonia & \\
\hline IGFBP-1: insulin like growth factor binding protein-1, HI/HA:hyperinsulinism/hyperammonaemia & \\
\hline
\end{tabular}

Table 2. Drugs used in the management of congenital hyperinsulinemic hypoglycaemia

\begin{tabular}{|c|c|c|c|c|}
\hline Medication & $\begin{array}{l}\text { Route of } \\
\text { administration }\end{array}$ & Dose & Mechanism of action & Side effects \\
\hline Diazoxide & Oral & $\begin{array}{l}5-20 \mathrm{mg} / \mathrm{kg} / \text { day, divided } \\
\text { into } 3 \text { doses }\end{array}$ & $\mathrm{K}_{\text {ATP }}$ channel agonist & $\begin{array}{l}\text { Common: Fluid retention, hypertrichosis, loss } \\
\text { of appetite } \\
\text { Rare: Cardiac failure, hyperuricemia, } \\
\text { leukopenia }\end{array}$ \\
\hline $\begin{array}{l}\text { Chlorothiazide (in } \\
\text { conjunction with } \\
\text { diazoxide) }\end{array}$ & Oral & $\begin{array}{l}5-10 \mathrm{mg} / \mathrm{kg} / \text { day, divided } \\
\text { into } 2 \text { doses }\end{array}$ & $\begin{array}{l}\text { Synergistic effect with } \\
\text { diazoxide; activation of } \\
K_{\text {ATP }} \text { channels }\end{array}$ & Hyponatremia, hypokalemia \\
\hline Nifedipine & Oral & $\begin{array}{l}0.25-2.5 \mathrm{mg} / \mathrm{kg} / \mathrm{day}, \\
\text { divided into } 3 \text { doses }\end{array}$ & Calcium channel blocker & Hypotension \\
\hline Octreotide & $\begin{array}{l}\text { s.c. injection/ } \\
\text { s.c. continuous } \\
\text { infusion }\end{array}$ & $5-35 \mathrm{ug} / \mathrm{kg} / \mathrm{day}$ & $\begin{array}{l}\text { Somatostatin analogue, } \\
\text { inhibits insulin secretion, } \\
\text { reduces insulin } \\
\text { biosynthesis, acts on the } \\
\mathrm{K}_{\text {ATP }} \text { channel }\end{array}$ & $\begin{array}{l}\text { Acute: Anorexia, nausea, abdominal } \\
\text { distension, drug-induced hepatitis, } \\
\text { steatorrhoea, long QT syndrome, } \\
\text { tachyphylaxis, necrotising enterocolitis } \\
\text { Long term: Decreased intestinal motility, bile } \\
\text { sludge, cholelithiasis, suppression of growth } \\
\text { hormone, thyroid stimulating hormone, } \\
\text { adrenocorticotropic hormone }\end{array}$ \\
\hline $\begin{array}{l}\text { Lanreotide (long-acting } \\
\text { somatostatin analogue) }\end{array}$ & i.m./deep s.c. & $\begin{array}{l}30-60 \mathrm{mg} / \text { dose every } 4 \\
\text { weeks (to be used in } \\
\text { children }>1 \text { year of age) }\end{array}$ & Same as octreotide & $\begin{array}{l}\text { Theoretically same as octreotide, clinically } \\
\text { less frequent than in octreotide }\end{array}$ \\
\hline Glucagon & $\begin{array}{l}\text { s.c./i.m. bolus } \\
\text { s.c./i.v. infusion }\end{array}$ & $\begin{array}{l}0.02 \mathrm{mg} / \mathrm{kg} / \text { dose or } 5-10 \\
\mathrm{ug} / \mathrm{kg} / \mathrm{h} \text { infusion }\end{array}$ & $\begin{array}{l}\text { Increases glycogenolysis } \\
\text { and gluconeogenesis }\end{array}$ & $\begin{array}{l}\text { Nausea, vomiting, skin rash, in high doses } \\
\text { ( }>20 \mathrm{ug} / \mathrm{kg} / \mathrm{h} \text { ) paradoxical insulin secretion } \\
\text { and rebound hypoglycaemia }\end{array}$ \\
\hline Sirolimus & Oral & $\begin{array}{l}\text { Treatment initiated on } 0.5 \\
\mathrm{mg} / \mathrm{m}^{2} \text {, divided into } 1-2 \\
\text { doses; } \\
\text { dose gradually increased } \\
\text { until reaching serum } \\
\text { levels of } 5-10 \mathrm{ng} / \mathrm{mL}\end{array}$ & $\begin{array}{l}\text { mTOR inhibitor, reduction } \\
\text { of } \beta \text {-cell proliferation, } \\
\text { inhibition of insulin } \\
\text { production }\end{array}$ & $\begin{array}{l}\text { Stomatitis, increased risk of infection, } \\
\text { immunosuppression, abnormalities in renal } \\
\text { function, fatigue, pneumonitis, transient } \\
\text { elevations of aminotransferase levels }\end{array}$ \\
\hline
\end{tabular}




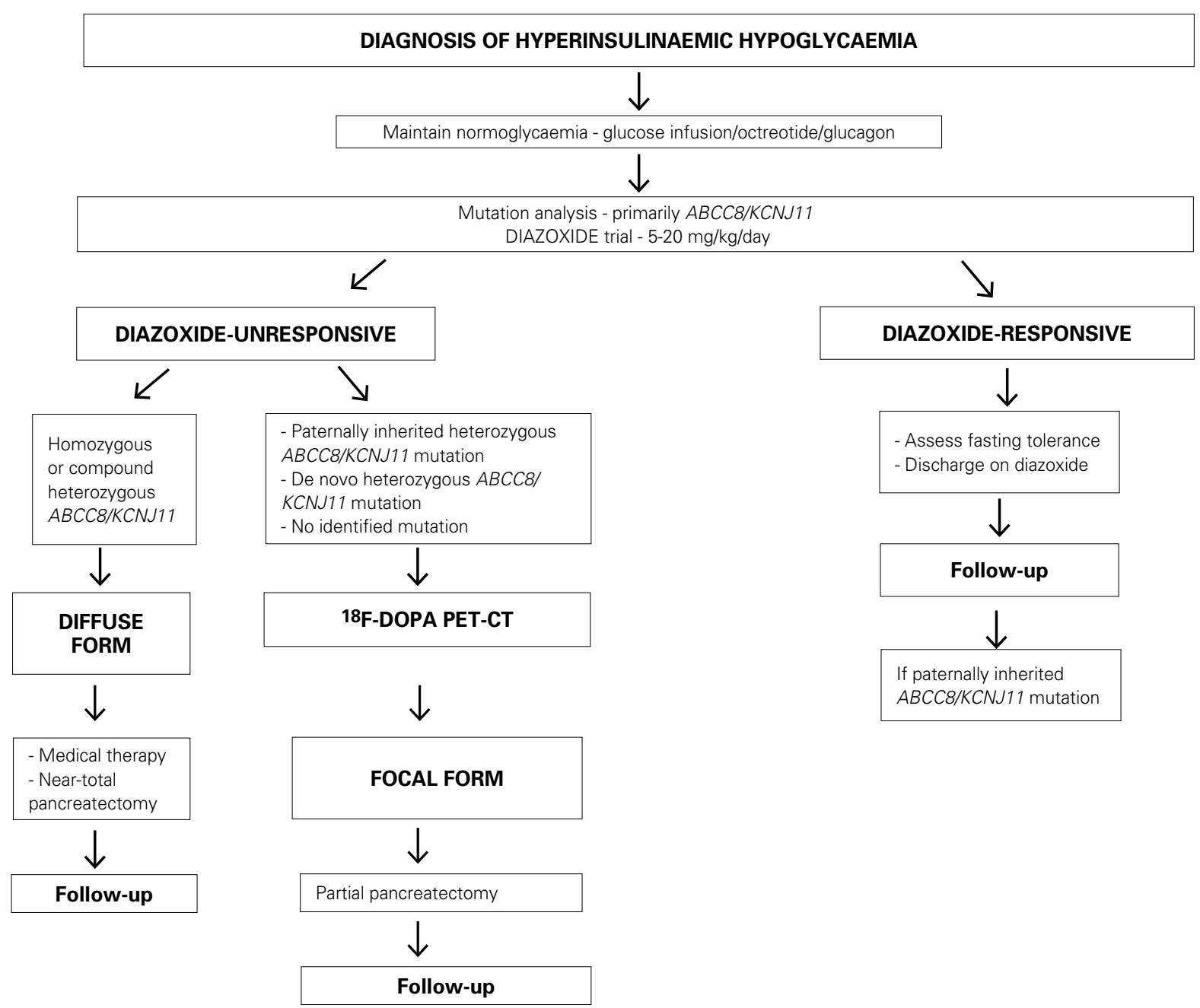

Figure 2. Proposed management algorithm for the treatment of congenital hyperinsulinism

abnormalities, hyperpigmentation, undescended testes or micropenis may suggest hypopituitarism.

It is paramount to diagnose $\mathrm{HH}$ as early as possible to avoid hypoglycaemic brain injury. Despite the difficulty in defining a cut-off concentration of blood glucose that suits all ages and conditions that present with hypoglycaemia, the level most consistently used worldwide to define hypoglycaemia for patients with $\mathrm{HH}$ is $3.5 \mathrm{mmol} / \mathrm{L}$ (63 $\mathrm{mg} / \mathrm{dL}$ ). This higher threshold of blood glucose concentration is recommended in view of the absence of ketones as an alternative source of energy for the brain in this group of patients. Patients with $\mathrm{HH}$ have glucose requirements $>8 \mathrm{mg} / \mathrm{kg} / \mathrm{min}$ (normal glucose requirements: $4-6 \mathrm{mg} / \mathrm{kg} / \mathrm{min}$ ) and this is also one of the diagnostic criteria for $\mathrm{HH}$ (1).

The biochemical results will be informative only if taken at the time of hypoglycaemia. The diagnostic fast should be carried out in a controlled environment adjusting to the physiological fasting time expected for age. In $\mathrm{HH}$, an inappropriate insulin and/or C-peptide concentration will be detected at the time of hypoglycaemia, with simultaneous poor response of ketone bodies and plasma non-esterified free fatty acids (1). The level of insulin achieved during hypoglycaemia is not indicative of the severity of the condition (1). A low insulin growth factor binding protein 1 (/GFBP-1) is also a marker of $\mathrm{HH}$ because the transcription of gene IGFBP-1 is suppressed by insulin (73). Other stress hormones such as cortisol and growth hormone should increase in the presence of hypoglycaemia and hence excluding these hormone deficiencies as the cause of hypoglycaemia. Urine organic acids, plasma amino acids, lactate and carnitines also need to be analysed in this test to rule out metabolic diseases. Table 1 summarises the biochemical criteria for $\mathrm{HH}$.

In some cases, the diagnosis of $\mathrm{HH}$ can be difficult, so in these cases, certain stimulation tests can aid with the diagnosis. A positive glycaemic response (glucose increment of $>1.5 \mathrm{mmol} / \mathrm{L}$ ) to i.m./i.v. glucagon at the time of hypoglycaemia is compatible with $\mathrm{HH}$ (74). In $\mathrm{HH}$, a positive glycaemic 
response will also be found after subcutaneous octreotide administration.

In HI/HA syndrome, the serum ammonia concentrations may be normal or raised (75), so the diagnosis requires a fast and a protein/leucine load test which will precipitate hypoglycaemia (30). Raised plasma hydroxyl-butyrylcarnitine and urinary 3-hydroxyglutarate are suggestive of HADH deficiency (36). If exercise-induced $\mathrm{HH}$ is suspected, then hypoglycaemia will need to be demonstrated in a formal exercise test or pyruvate load test (40). To confirm the diagnosis of postprandial $\mathrm{HH}$, the test to use is a mixed meal test or an oral glucose tolerance test (76).

In those cases where there is no response to therapy with diazoxide, DNA on the patient and parents should be collected and sent for genetic analysis as the result will guide to the diagnosis (focal versus diffuse disease) and management. A genetic mutation will be found in $80-90 \%$ of diazoxide-unresponsive patients. Homozygous and compound heterozygous mutations in $A B C C 8$ and $K C N J 11$ genes usually explain cases of diffuse disease, whereas paternally inherited mutations in these two genes are most commonly associated with focal disease (9). Mutations found in other genes not encoding the $\mathrm{K}_{\text {ATP }}$ channel will also shed light onto the appropriate management.

If the genetic findings are suggestive of focal disease, then the next step will be to perform 18F-DOPA PET-CT scan. The importance of this PET scan resides in the need to distinguish between the focal and the diffuse form of $\mathrm{CHI}$ as the surgical approach varies enormously between the two. This imaging technique has become, over the last years, the gold standard to localize the focal lesion within the pancreas (77) with the capacity to differentiate it from diffuse disease with $89 \%$ and $98 \%$ sensitivity and specificity, respectively (78). These results are much better than traditional imaging methods such as CT and MRI. Unlike trans-hepatic portal vein cannulation or pancreatic arteriography, PET scan is also appreciated for its non-invasiveness while maintaining high accuracy (79).

Pancreatic islets take up 18F-DOPA and convert it into dopamine using the enzyme DOPA decarboxylase. Focal and diffuse forms of $\mathrm{HH}$ have an increased activity of this enzyme (9). Uniform 18F-DOPA uptake throughout the whole pancreas is indicative of diffuse disease, in the contrary to the focal lesion, where the accumulation of 18F-DOPA within the lesion is markedly increased when compared to the surrounding tissue (80). The limitations of this technique are its availability in only a few centers around the world and the expertise required in the interpretation of the images.

\section{Management of the Different Forms of $\mathrm{HH}$}

The management of $\mathrm{HH}$ is very complex, yet a prompt and adequate therapy helps to prevent further episodes of hypoglycaemia, subsequent brain damage and other neurodevelopmental impairments (1).
The primary aim of management is to keep the blood glucose levels within the normal range $(3.5-5.5 \mathrm{mmo} / \mathrm{L})$ and to establish an appropriate fasting tolerance for age and a normal feeding pattern (15).

The management of $\mathrm{HH}$ may include dietary, medical and surgical approach, being in the majority of cases, a combination of these. The acute management is identical for all types of $\mathrm{HH}$ ensuring the stabilization of the blood glucose levels. This provides the clinician with time to determine the specific cause of $\mathrm{HH}$ and to introduce appropriate long-term therapy. Given the fact that it is a relatively rare condition with a challenging management, it is recommended that these patients are referred to tertiary centers that have the necessary experience and expertise in managing this condition (18).

\section{Acute Therapy}

Parenteral glucose infusion: The cornerstone of the immediate therapy is to provide sufficient glucose to maintain normoglycaemia. In respect to the biochemical basis of the hypoglycaemia (absence of ketone bodies), a higher threshold of blood glucose concentration should be aimed ( $>3.5 \mathrm{mmo} / \mathrm{L}$ ) (81). The parenteral glucose requirements exceed $8 \mathrm{mg} / \mathrm{kg} /$ min and can often be as high as $15-25 \mathrm{mg} / \mathrm{kg} / \mathrm{min}$, thus in the severe forms of $\mathrm{HH}$, the insertion of a central venous access may be required to deliver concentrated solutions of glucose $(15,18,26)$. Parenteral glucose therapy can be supported with enteral feeding (15).

Frequent feeding: This is a very important supportive method in managing $\mathrm{HH}$ patients, although often difficult due to the feeding disturbances, food aversion, gastro-esophageal reflux disease and foregut dysmotility observed in patients with $\mathrm{HH}$ (82). These common problems can partially be explained as the side effects of the administered medicines, but also possibly influenced by an unknown mechanism shared by all types of HH patients. It is often necessary to deliver feeds via nasogastric tube or gastrostomy in order to keep blood glucose levels in the normal range.

Glucagon: In case of emergency (e.g. symptomatic hypoglycaemia and seizures without a venous access), intramuscular administration of glucagon may be used $(9,18,83,84)$. The recommended single dose is between $0.5-1 \mathrm{mg}$ (82). Glucagon increases the blood glucose within a few minutes by inducing glycogenolysis, gluconeogenesis, ketogenesis and lipolysis $(9,18,83,84)$. The use of glucagon has also been reported as a long-term management via a subcutaneous infusion (85). The dose should be 5-10 $\mathrm{ug} / \mathrm{kg} / \mathrm{h}$ if administered as an infusion (82). Glucagon can be used on its own or in a combination with octreotide in severe $\mathrm{HH}$ cases, when refractory hypoglycaemia persists despite high parenteral glucose intake. However, high doses of glucagon may paradoxically stimulate insulin secretion and increase glucose infusion requirements or cause further, rebound hypoglycaemia. Hence, glucagon doses above 10 $\mathrm{ug} / \mathrm{kg} / \mathrm{h}$ should be omitted (86). 


\section{Long-Term Therapy}

Further management of the different types of $\mathrm{HH}$ may differ. The identification of the specific type of $\mathrm{HH}$ can be done with help of rapid molecular genetic testing for the common $\mathrm{CHI}$ genes (ABCC8,KCNJ11) and targeted genetic testing for the less common genes if suggested by the phenotype. In indicated cases, further diagnosis can be made using 18F-DOPA PET-CT scan $(9,15,18,79,83)$ to distinguish between the focal and the diffuse forms of $\mathrm{CHI}$. In case of a focal form, the patients are cured by partial pancreatectomy, removing only the affected part of the pancreas that is producing excessive amount of insulin, while keeping the rest, ensuring sufficient exocrine and endocrine functions $(84,87)$. On the other hand, in diffuse disease $\mathrm{HH}$, the aim is to find a suitable medical therapy to avoid a near-total pancreatectomy $(18,84)$.

The therapeutic approach will be different between those that are diazoxide-responsive and diazoxide-unresponsive cases. The management of diazoxide-responsive patients is straightforward, while the management of diazoxideunresponsive cases is much more challenging. The clinician should try to find a suitable medical therapy or if necessary, in case of medically unresponsive cases, to resort to surgical therapy $(9,18,82,83,88)$.

Identification of much rarer cases of $\mathrm{CHI}$, such as GLUD1, HADH or SLC16A1 gene mutations, may transform management strategies in these patients. GLUD1 and HADH mutation-positive patients are usually protein-sensitive $(29,37)$ and reducing the protein in the diet can significantly decrease the number of hypoglycaemic episodes that they experience. Whereas hypoglycaemia in SLC16A1 mutation carriers is exercise-induced and it is the anaerobic type of exercise that these patients need to eliminate in order to minimize the number of hypoglycaemic episodes (40).

A detailed management algorithm is summarized in Figure 2.

\section{Medical Therapy}

The list of drugs used in the management of $\mathrm{HH}$ is summarized in Table 2.

Diazoxide: The first-line therapy for all types of $\mathrm{HH}$ is the oral administration of diazoxide. Diazoxide binds to the SUR1 subunit causing opening of the intact $K_{\text {ATP }}$ channels, which results in the blockade of $\beta$-cell depolarization and subsequent reduction of insulin secretion $(1,9,18,19,83,89)$. This is basically the opposite mechanism of action than that observed with the oral hypoglycaemic agent sulphonylurea (90).

Based on the clinical response to therapy with diazoxide, the patients can be divided into two groups: diazoxideresponsive and diazoxide-unresponsive. In a recently published cohort of 300 patients, $63.5 \%$ were diazoxide-responsive and $36.5 \%$ diazoxide-unresponsive (5). This responsiveness is based on the fact that intact $K_{\text {ATP }}$ channels are required for diazoxide to work. Therefore, children with diffuse disease due to inactivating mutations in $A B C C 8$ and $K C N J 11$ and most patients with focal lesions are usually diazoxide-unresponsive
$(9,18,19,83,89)$. On the other hand, patients carrying mutations in the remaining known $\mathrm{CHI}$ genes are usually diazoxideresponsive $(5,15)$.

To assess the effect of treatment with diazoxide, this should be started orally at $5 \mathrm{mg} / \mathrm{kg} /$ day in three divided doses and the dose can be gradually increased, if needed, up to a maximum dose of $20 \mathrm{mg} / \mathrm{kg} / \mathrm{day}$. Diazoxide should be tried on the maximum dose for at least 5 subsequent days before the patient can be described as unresponsive (89). For patients who do not respond to diazoxide, further increase of the dose would result in an increased risk of side effects.

If the patients are diazoxide-responsive, the positive effect on the blood glucose levels can often be observed before reaching the maximum dose, hence upper limit doses are not usually necessary. The most commonly observed and also the most serious side effect is fluid retention. It occurs mostly in the neonatal period and in at-risk patients may lead to the development of congestive heart failure and pulmonary hypertension (91). Therefore, chlorothiazide $(5-10 \mathrm{mg} / \mathrm{kg} / \mathrm{day}$ in 2 divided doses), a thiazide diuretic, is usually introduced together with diazoxide. It is used to prevent fluid retention, but it is also convenient for its synergistic effect on the suppression of insulin secretion $(9,18,84)$. In older children, if there is no evidence of fluid retention, therapy with chlorothiazide is not necessary. Other common side effect of diazoxide is hypertrichosis, which may be very pronounced and could be a source of stress for the whole family. Fortunately, this side effect is fully reversible after discontinuation of therapy with diazoxide (91). Less common side effects may include nausea, vomiting, feeding problems, hyperuricaemia, tachycardia and leukopenia (91).

If the daily dose of diazoxide required to maintain normoglycaemia falls below $5 \mathrm{mg} / \mathrm{kg} /$ day, then discontinuation of the treatment should be considered in a hospital setting (88).

Octreotide: This is the second line of medical therapy for children with diazoxide-unresponsive $\mathrm{CHI}$. Octreotide is a longacting somatostatin analogue that inhibits insulin secretion from pancreatic $\beta$-cells. This is mediated by binding to the somatostatin receptor SSTR5 which then inhibits calcium mobilization and acetylcholine activity therefore decreasing the insulin gene promoter activity which results in reduced insulin biosynthesis (90). Somatostatin may also exhibit an effect on insulin secretion through its action on the K KTP channel (18).

The recommended dose of octreotide is $5-35 \mathrm{ug} / \mathrm{kg} / \mathrm{day}$ and it can be administered either by 3-4 daily subcutaneous injections or as a continuous subcutaneous infusion (92). Octreotide exhibits a rapid increase of blood glucose level after administration of the first dose, but this may be followed by tachyphylaxis, which causes a rapid decline in response to octreotide 24-48 hours after initiation of therapy. Tachyphylaxis is generally transient and can be managed by dose adjustment $(9,18,82,83)$. Potential adverse effects of octreotide include acute anorexia, nausea, abdominal pain, diarrhoea, drug-induced hepatitis, long QT syndrome and development of necrotizing enterocolitis (93). Long-term side effects include decreased 
intestinal motility, bile sludge, gallstone and suppression of pituitary hormones (growth hormone and thyroid stimulating hormone) (82).

Long-acting somatostatin analogues: Recently, two prolongedreleased formulations of synthetic somatostatin analogues LAR-octreotide and lanreotide - have been successfully used in children with $\mathrm{CHI}$ (94). Long-acting octreotide is administered as intramuscular or deep subcutaneous injection every 4 weeks, which positively influences families' compliance and improves the patients' quality of life (82). Although the number of patients studied so far is limited and more studies are required to look into the long-term effectiveness of this medication, all the patients had the same or better response to long-acting octreotide than to previous medication (3-4 daily subcutaneous injections of short-acting octreotide and intensive feeding regime). Moreover, none of the severe side effects was observed (94).

Nifedipine: Reduction of insulin secretion during administration of nifedipine has been described in several cases of patients with $\mathrm{HH}(95,96,97,98,99,100,101)$. Nifedipine is a calcium channel blocker and inhibits insulin secretion by inactivating the voltage-gated calcium channels. However, the vast majority of $\mathrm{HH}$ patients fails to show any response and calcium channel blockers are not regularly being used in the treatment of $\mathrm{HH}$ (96). But given the role of the voltagegated calcium channels in regulating insulin secretion, more standardized studies and trials on $\mathrm{HH}$ patients are required before completely ruling out this medication from management of $\mathrm{HH}$.

\section{New Perspectives}

Sirolimus: Recently, the mammalian target of rapamycin (mTOR) inhibitor sirolimus has been successfully used in several patients with diffuse $\mathrm{HH}$ who were un-responsive to maximum doses of diazoxide and octreotide (102). The excessive activation of the mTOR pathway plays a role in the pathogenesis of $\mathrm{HH}$ (103). The use of mTOR inhibitor sirolimus reduces the $\beta$-cell proliferation and inhibits insulin production therefore resulting in a clinically significant glycemic response. The authors have not reported any major side effects during 1 year of follow-up (102).

Exendin: The GLP-1 receptor antagonist exendin-(9-39) has recently been reported to elevate fasting blood glucose level in adults with $\mathrm{K}_{\text {ATP }} \mathrm{HH}$ (104). Therefore, it has been suggested that exendin could represent a novel therapeutic target to manage hypoglycemia in $\mathrm{HH}$ patients. However, further clinical studies are needed to assess its effectiveness, safety, and pharmacokinetics.

\section{Surgical Therapy}

The indications for surgery in $\mathrm{CHI}$ patients include confirmed focal disease on 18F-DOPA-PET-CT scan and medically un-responsive diffuse disease.

Focal form: The focal form of $\mathrm{CHI}$ has been reported in about $40-65 \%$ of all patients treated surgically $(6,21)$. The treatment of choice for patients with the focal form of $\mathrm{CHI}$ is partial pancreatectomy. After removing the affected part of pancreas, the patients should be completely cured from the hypoglycaemia (105). The exact localization of the focal lesion is made using 18F-DOPA PET-CT that helps to guide the surgeon during the surgery (79). If the lesion is localized in the body or in the tail of the pancreas, laparoscopic approach should be used. Recent studies show that the accuracy and success of the laparoscopic approach is comparable to open surgery while benefiting from a shorter post-operative care and minor patients' trauma after a keyhole surgery (106). On the other hand, if the lesion is in a surgically difficultly accessible location (for example in the pancreatic head), open laparotomy may be needed. In a group of 47 patients who underwent partial pancreatectomy for an evident focal lesion, $100 \%$ of cases were completely cured and none of them required insulin therapy after the operation (107).

Diffuse form: The last resort for patients with medically unresponsive diffuse form of $\mathrm{HH}$ is a near-total pancreatectomy (21). However, some children remain hypoglycaemic despite the removal of $95-98 \%$ of pancreatic tissue. Then, a further attempt to control the condition with diazoxide therapy can be made. In a study that included 58 children who underwent neartotal pancreatectomy, 59\% of them remained hypoglycaemic immediately after surgery or later. However, the hypoglycaemic episodes were not as severe, occurred mainly pre-prandially, mostly at the end of an all-night fast and could be managed by adjusting the feeding regime or medication (107). In addition, with increasing age the severity of these hypoglycaemic episodes decreased and at the time of 5 years after surgery these episodes were recorded only in a few isolated cases (107). In a minority of cases, further re-operation and total pancreatectomy may be necessary to control severe $\mathrm{CHI}$ (87).

Near-total pancreatectomy unfortunately carries a high risk of exocrine pancreatic insufficiency and development of diabetes mellitus later in life (108). In some cases, hyperglycaemia may occur within the first days after surgery, thereafter, the incidence of hyperglycaemia gradually increases with age. The need for insulin therapy is $19 \%$ immediately after surgery and goes up to $91 \%$ at age of 14 years (107).

Given these risks, medical therapy is preferred when possible (87). In recent years, the number of patients undergoing these procedures has dropped, that is due to recent advances in pharmacotherapy.

Follow-up

Given the complexity of this condition, $\mathrm{HH}$ patients need to be regularly followed up in regards to their glycemic response but also in regards to their neurological development and other possibly related conditions in the case of syndromic $\mathrm{HH}$. The parents/carers need to be educated in home blood glucose monitoring and what measures to take in case of hypoglycaemia (hypoplan).

Children with diffuse disease on medical therapy should have 24-hour blood glucose profile and fasting tolerance regularly checked to optimize medical therapy as they may need adjustments in the medication dose due to their weight gain. Some children, on the other hand, may need therapy adjustments as their $\mathrm{HH}$ gets milder as they grow older. 
Children with diffuse disease that undergo subtotal (95\%)، near-total $(98 \%)$ or subsequent total pancreatectomy have to be closely followed up particularly concentrating on signs for the onset of diabetes mellitus, as the percentage of children developing insulin-dependent diabetes following these procedures is extremely high (107).

In contrast, children with a focal form of $\mathrm{CH}$ that have been completely cured following a resection of the pancreatic focal lesion do not require an intensive follow-up.

In case of $\mathrm{CHI}$ caused by genetic defects in pancreatic transcription factors genes (HNF4A, HNF1A), it is essential to adjust the dose of diazoxide as $\mathrm{HH}$ in these cases is transient and subsides in childhood. These children are then expected to develop non-autoimmune diabetes (MODY) later in early adulthood (46). It is therefore crucial that these children are not lost to follow-up and the nature of this genetic condition is properly explained to the parents as well as to the patients.

\section{Conclusion}

$\mathrm{HH}$ is an important cause of hypoglycaemia in the newborn and childhood period, therefore prompt diagnosis is the key in the management of $\mathrm{HH}$ patients. Although there has been a huge progress in the diagnosis and management of patients with $\mathrm{CHI}$, it still remains a challenging condition for the clinicians. Molecular genetics brings new possibilities into the diagnostics, unraveling the processes leading to hyperinsulinism. Along with novel imaging techniques (such as 18F-DOPA PET-CT), new medications and laparoscopic surgery have dramatically improved the outcome of $\mathrm{CHI}$ patients over the last decade. However, genetic etiology remains unknown in approximately $80 \%$ of diazoxide-responsive and $10 \%$ of diazoxide-unresponsive cases, thus suggesting that there are yet unidentified genetic causes of $\mathrm{HH}$ (109). Therefore, further research is required to identify new involved genes and to develop novel therapeutic therapies.

\section{References}

1. Aynsley-Green A, Hussain K, Hall J, Saudubray JM, NihoulFékété $\mathrm{C}$, De Lonlay-Debeney $\mathrm{P}$, Brunelle $\mathrm{F}$, Otonkoski

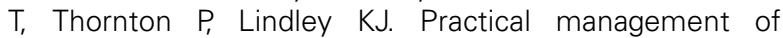
hyperinsulinism in infancy. Arch Dis Child Fetal Neonatal Ed 2000;82:98-107.

2. Hussain K, Aynsley-Green A. Hyperinsulinism in infancy: understanding the pathophysiology. Int J Biochem Cell Biol 2003;35:1312-1317

3. Harris DL, Weston PJ, Harding JE. Lactate, rather than ketones, may provide alternative cerebral fuel in hypoglycaemic newborns. Arch Dis Child Fetal Neonatal Ed 2015;100:161164. Epub 2014 Sep 4

4. Arya VB, Flanagan SE, Kumaran A, Shield JP, Ellard S, Hussain K, Kapoor RR. Clinical and molecular characterisation of hyperinsulinaemic hypoglycaemia in infants born smallfor-gestational age. Arch Dis Child Fetal Neonatal Ed 2013;98:356-358. Epub 2013 Jan 29

5. Kapoor RR, Flanagan SE, Arya VB, Shield JP, Ellard S, Hussain K. Clinical and molecular characterisation of 300 patients with congenital hyperinsulinism. Eur J Endocrinol 2013;168:557-564.

6. Pierro A, Nah SA. Surgical management of congenital hyperinsulinism of infancy. Semin Pediatr Surg 2011;20:50-53.

7. Kapoor RR, Heslegrave A, Hussain K. Congenital hyperinsulinism due to mutations in HNF4A and HADH. Rev Endocr Metab Disord 2010;11:185-191.

8. Flanagan SE, Kapoor RR, Hussain K. Genetics of congenital hyperinsulinemic hypoglycemia. Semin Pediatr Surg 2011;20:13-17.

9. Senniappan S, Shanti B, James C, Hussain K. Hyperinsulinaemic hypoglycaemia: genetic mechanisms, diagnosis and management. J Inherit Metab Dis 2012;35:589601. Epub 2012 Jan 10

10. Thomas PM, Cote GJ, Wohllk N, Haddad B, Mathew PM, Rabl W, Aguilar-Bryan L, Gagel RF, Bryan J. Mutations in the sulfonylurea receptor gene in familial persistent hyperinsulinemic hypoglycemia of infancy. Science 1995;268:426-429.

11. Kane C, Shepherd RM, Squires PE, Johnson PR, James RF, Milla PJ, Aynsley-Green A, Lindley KJ, Dunne MJ. Loss of functional KATP channels in pancreatic beta-cells causes persistent hyperinsulinemic hypoglycemia of infancy. Nat Med 1996;2:1344-1347.

12. Glaser B. Lessons in human biology from a monogenic pancreatic beta cell disease. J Clin Invest, 2011;121:38213825.

13. Dunne MJ, Kane C, Shepherd RM, Sanchez JA, James RF, Johnson PR, Aynsley-Green A, Lu S, Clement JP 4th, Lindley KJ, Seino S, Aguilar-Bryan L. Familial persistent hyperinsulinemic hypoglycemia of infancy and mutations in the sulfonylurea receptor. N Engl J Med 1997;336:703-706.

14. Nestorowicz A, Wilson BA, Schoor KP, Inoue $H$, Glaser $B$, Landau H, Stanley CA, Thornton PS, Clement JP 4th, Bryan $J$, Aguilar-Bryan L, Permutt MA. Mutations in the sulonylurea receptor gene are associated with familial hyperinsulinism in Ashkenazi Jews. Hum Mol Genet 1996;5:1813-1822.

15. Kapoor RR, Flanagan SE, James C, Shield J, Ellard S, Hussain K. Hyperinsulinaemic hypoglycaemia. Arch Dis Child 2009;94:450-457. Epub 2009 Feb 4

16. Hussain K, Aynsley-Green A. Management of hyperinsulinism in infancy and childhood. Ann Med 2000;32:544-551.

17. Pinney SE, MacMullen C, Becker S, Lin YW, Hanna C, Thornton P, Ganguly A, Shyng SL, Stanley CA. Clinical characteristics and biochemical mechanisms of congenital hyperinsulinism associated with dominant KATP channel mutations. J Clin Invest 2008;118:2877-2886.

18. Hussain K. Diagnosis and management of hyperinsulinaemic hypoglycaemia of infancy. Horm Res 2008;69:2-13. Epub 2007 Dec 4

19. Macmullen CM, Zhou Q, Snider KE, Tewson PH, Becker SA, Aziz AR, Ganguly A, Shyng SL, Stanley CA. Diazoxideunresponsive congenital hyperinsulinism in children with dominant mutations of the beta-cell sulfonylurea receptor SUR1. Diabetes 2011;60:1797-1804. Epub 2011 May 2

20. Zani A, Nah SA, Ron O, Totonelli G, Ismail D, Smith $W$, Ashworth M, Blankenstein O, Mohnike W, De Coppi P, Eaton $S$, Hussain K, Pierro A. The predictive value of preoperative fluorine-18-L-3,4-dihydroxyphenylalanine positron emission tomography-computed tomography scans in children with congenital hyperinsulinism of infancy. J Pediatr Surg 2011;46:204-208.

21. Fékété $C N$, de Lonlay $P$, Jaubert $F$, Rahier J, Brunelle $F$, Saudubray JM. The surgical management of congenital hyperinsulinemic hypoglycemia in infancy. J Pediatr Surg 2004;39:267-269. 
22. Rahier J, Guiot Y, Sempoux C. Morphologic analysis of focal and diffuse forms of congenital hyperinsulinism. Semin Pediatr Surg 2011;20:3-12.

23. Delonlay P, Simon A, Galmiche-Rolland L, Giurgea I, Verkarre $V$, Aigrain $Y$, Santiago-Ribeiro MJ, Polak M, Robert JJ, Bellanne-Chantelot C, Brunelle F,Nihoul-Fekete C, Jaubert F. Neonatal hyperinsulinism: clinicopathologic correlation. Hum Pathol 2007;38:387-399.

24. James C, Kapoor RR, Ismail D, Hussain K. The genetic basis of congenital hyperinsulinism. J Med Genet 2009;46:289299. Epub 2009 Mar 1

25. Hussain K, Flanagan SE, Smith VV, Ashworth M, Day M, Pierro A, Ellard S. An ABCC8 gene mutation and mosaic uniparental isodisomy resulting in atypical diffuse congenital hyperinsulinism. Diabetes 2008;57:259-263. Epub 2007 Oct 17

26. Arya VB, Senniappan S, Guemes M, Hussain K. Neonatal hypoglycemia. Indian J Pediatr 2014;81:58-65. Epub 2013 Aug 1

27. Huopio H, Reimann F, Ashfield R, Komulainen J, Lenko $\mathrm{HL}$, Rahier J, Vauhkonen I, Kere J, Laakso M, Ashcroft F, Otonkoski T. Dominantly inherited hyperinsulinism caused by a mutation in the sulfonylurea receptor type 1. J Clin Invest 2000;106:897-906.

28. Flanagan SE, Kapoor RR, Banerjee I, Hall C, Smith WV, Hussain K, Ellard S. Dominantly acting ABCC8 mutations in patients with medically unresponsive hyperinsulinaemic hypoglycaemia. Clin Genet 2011;79:582-587.

29. Stanley CA, Lieu YK, Hsu BY, Burlina AB, Greenberg $C R$, Hopwood NJ, Perlman K, Rich BH, Zammarchi E, Poncz $M$. Hyperinsulinism and hyperammonemia in infants with regulatory mutations of the glutamate dehydrogenase gene. N Engl J Med 1998;338:1352-1357.

30. Kapoor RR, Flanagan SE, Fulton P, Chakrapani A, Chadefaux B, Ben-Omran T, Banerjee I, Shield JP, Ellard S, Hussain K. Hyperinsulinism-hyperammonaemia syndrome: novel mutations in the GLUD1 gene and genotype-phenotype correlations. Eur J Endocrinol 2009;161:731-735. Epub 2009 Aug 18

31. Meissner T, Mayatepek E, Kinner M, Santer R. Urinary alphaketoglutarate is elevated in patients with hyperinsulinismhyperammonemia syndrome. Clin Chim Acta 2004;341:23-26.

32. Matschinsky FM. Regulation of pancreatic betacell glucokinase: from basics to therapeutics. Diabetes 2002;51(Suppl 3):394-404.

33. Glaser B, Kesavan P, Heyman M, Davis E, Cuesta A, Buchs A, Stanley CA, Thornton PS, Permutt MA, Matschinsky FM, Herold KC. Familial hyperinsulinism caused by an activating glucokinase mutation. N Engl J Med 1998;338:226-230.

34. Wabitsch $M$, Lahr $G$, Van de Bunt $M$, Marchant $C$, Lindner $M$, von Puttkamer J, Fenneberg A, Debatin KM, Klein R, Ellard $S$, Clark A, Gloyn AL. Heterogeneity in disease severity in a family with a novel G68V GCK activating mutation causing persistent hyperinsulinaemic hypoglycaemia of infancy. Diabet Med 2007;24:1393-1399. Epub 2007 Nov 1

35. Cuesta-Muñoz AL, Huopio H, Otonkoski T, GomezZumaquero JM, Näntö-Salonen K, Rahier J, López-Enriquez S, García-Gimeno MA, Sanz P, Soriguer FC, Laakso M. Severe persistent hyperinsulinemic hypoglycemia due to a de novo glucokinase mutation. Diabetes 2004;53:2164-2168.

36. Vredendaal $P J$, van den Berg IE, Malingré HE, Stroobants AK, Olde Weghuis DE, Berger R. Human short-chain L-3hydroxyacyl-CoA dehydrogenase: cloning and characterization of the coding sequence. Biochem Biophys Res Commun 1996;223:718-723.

37. Clayton PT, Eaton S, Aynsley-Green A, Edginton M, Hussain K, Krywawych S, Datta V, Malingre HE, Berger R, van den
Berg IE. Hyperinsulinism in short-chain L-3-hydroxyacyl-CoA dehydrogenase deficiency reveals the importance of betaoxidation in insulin secretion. J Clin Invest 2001;108:457-465.

38. Molven A Matre GE, Duran $M$, Wanders RJ, Rishaug $U$, Njølstad PR, Jellum E, Søvik O. Familial hyperinsulinemic hypoglycemia caused by a defect in the SCHAD enzyme of mitochondrial fatty acid oxidation. Diabetes 2004;53:221227.

39. Flanagan SE, Patch AM, Locke JM, Akcay T, Simsek E, Alaei M, Yekta Z, Desai M, Kapoor RR, Hussain K, Ellard S. Genomewide homozygosity analysis reveals $\mathrm{HADH}$ mutations as a common cause of diazoxide-responsive hyperinsulinemichypoglycemia in consanguineous pedigrees. $\mathrm{J}$ Clin Endocrinol Metab 2011;96:498-502. Epub 2011 Jan 20

40. Otonkoski T, Jiao H, Kaminen-Ahola N, Tapia-Paez I, Ullah MS, Parton LE, Schuit F, Quintens R, Sipilä I, Mayatepek E, Meissner T, Halestrap AP, Rutter GA, Kere J. Physical exercise-induced hypoglycemia caused by failed silencing of monocarboxylate transporter 1 in pancreatic beta cells. Am J Hum Genet 2007;81:467-474. Epub 2007 Jul 26

41. Meissner T, Otonkoski T, Feneberg R, Beinbrech B, Apostolidou S, Sipila I, Schaefer F, Mayatepek E. Exercise induced hypoglycaemic hyperinsulinism. Arch Dis Child 2001; 84:254-257.

42. Otonkoski T, Kaminen N, Ustinov J, Lapatto R, Meissner T, Mayatepek E, Kere J, Sipilä I. Physical exercise-induced hyperinsulinemic hypoglycemia is an autosomal-dominant trait characterized by abnormal pyruvate-induced insulin release. Diabetes 2003;52:199-204.

43. González-Barroso MM, Giurgea I, Bouillaud $F$, Anedda $A$, Bellanné-Chantelot $C$, Hubert $L$, de Keyzer $Y$, de Lonlay $P$, Ricquier D. Mutations in UCP2 in congenital hyperinsulinism reveal a role for regulation of insulin secretion. PLoS One 2008;3:3850. Epub 2008 Dec 9

44. Gupta RK, Vatamaniuk MZ, Lee CS, Flaschen RC, Fulmer JT, Matschinsky FM, Duncan SA, Kaestner KH. The MODY1 gene HNF-4alpha regulates selected genes involved in insulin secretion. J Clin Invest 2005;115:1006-1015.

45. Pearson ER, Boj SF, Steele AM, Barrett T, Stals K, Shield JP, Ellard S, Ferrer J, Hattersley AT. Macrosomia and hyperinsulinaemic hypoglycaemia in patients with heterozygous mutations in the HNF4A gene. PLoS Med 2007;4:118.

46. Kapoor RR, Locke J, Colclough K, Wales J, Conn JJ, Hattersley AT, Ellard S, Hussain K. Persistent hyperinsulinemic hypoglycemia and maturity-onset diabetes of the young due to heterozygous HNF4A mutations. Diabetes 2008;57:16591663. Epub 2008 Feb 11

47. Yamagata K, Furuta H, Oda N, Kaisaki PJ, Menzel S, Cox NJ, Fajans SS, Signorini S, Stoffel M, Bell GI. Mutations in the hepatocyte nuclear factor-4alpha gene in maturity-onset diabetes of the young (MODY1). Nature 1996;384:458-460.

48. Pingul MM, Hughes N, Wu A, Stanley CA, Gruppuso PA. Hepatocyte nuclear factor $4 \alpha$ gene mutation associated with familial neonatal hyperinsulinism and maturity-onset diabetes of the young. J Pediatr 2011;158:852-854. Epub 2011 Feb 24

49. Stanescu DE, Hughes N, Kaplan B, Stanley CA, De León DD. Novel presentations of congenital hyperinsulinism due to mutations in the MODY genes: HNF1A and HNF4A. J Clin Endocrinol Metab 2012;97:2026-2030. Epub 2012 Jul 16

50. Dusatkova P, Pruhova S, Sumnik Z, Kolouskova $S$, Obermannova B, Cinek O, Lebl J. HNF1A mutation presenting with fetal macrosomia and hypoglycemia in childhood prior to onset of overt diabetes. J Pediatr Endocrinol Metab 2011;24:187-189. 
51. Bufler P, Ehringhaus C, Koletzko S. Dumping syndrome: a common problem following Nissen fundoplication in young children. Pediatr Surg Int 2001;17:351-355.

52. Foster-Schubert KE. Hypoglycemia complicating bariatric surgery: incidence and mechanisms. Curr Opin Endocrino Diabetes Obes 2011;18:129-133.

53. Palladino AA, Sayed S, Levitt Katz LE, Gallagher PR, De León DD. Increased glucagon-like peptide-1 secretion and postprandial hypoglycemia in children after Nissen fundoplication. J Clin Endocrinol Metab 2009;94:39-44. Epub 2008 Oct 28

54. Hirata Y. Insulin autoimmune syndrome. Nihon Rinsho 1973;31:2227-2231.

55. Huang Z, Li Y, Tang T, Xu W, Liao Z, Yao B, Hu G, Weng $J$. Hyperinsulinaemic hypoglycaemia associated with a heterozygous missense mutation of R1174W in the insulin receptor (IR) gene. Clin Endocrinol (Oxf) 2009;71:659-665. Epub 2009 Jan 19

56. Kosztolányi G. Leprechaunism/Donohue syndrome/insulin receptor gene mutations: a syndrome delineation story from clinicopathological description to molecular understanding. Eur J Pediatr 1997;156:253-255.

57. Shin JJ, Gorden P, Libutti SK. Libutti, Insulinoma: pathophysiology, localization and management. Future Oncol 2010;6:229-237.

58. Hussain K. Investigations for neonatal hypoglycaemia. Clin Biochem 2011;44:465-466

59. Kapoor RR, James C, Hussain K. Hyperinsulinism in developmental syndromes. Endocr Dev 2009;14:95-113. Epub 2009 Feb 27

60. Munss C, Batch J. Hyperinsulinism and Beckwith-Wiedemann syndrome. Arch Dis Child Fetal Neonatal Ed 2001;84:67-69.

61. Baujat G, Rio M, Rossignol S, Sanlaville D, Lyonnet S, Le Merrer M, Munnich A, Gicquel C, Cormier-Daire V, Colleaux L. Paradoxical NSD1 mutations in Beckwith-Wiedemann syndrome and $11 \mathrm{p} 15$ anomalies in Sotos syndrome. Am J Hum Genet 2004;74:715-720.

62. Terespolsky D, Farrell SA, Siegel-Bartelt J, Weksberg R. Infantile lethal variant of Simpson-Golabi-Behmel syndrome associated with hydrops fetalis. Am J Med Genet 1995;59:329-333.

63. Sanlaville D, Genevieve D, Bernardin C, Amiel J, Baumann C, de Blois MC, Cormier-Daire V, Gerard B, Gerard M, Le Merrer $M$, Parent P, Prieur F, Prieur $M$, Raoul $O$, Toutain A, Verloes A, Viot G, Romana S, Munnich A, Lyonnet S, Vekemans $\mathrm{M}$,Turleau C. Failure to detect an 8p22-8p23.1 duplication in patients with Kabuki (Niikawa-Kuroki) syndrome. Eur J Hum Genet 2005;13:690-693.

64. Alexander S, Ramadan D, Alkhayyat H, Al-Sharkawi I, Backer KC, El-Sabban F, Hussain K. Costello syndrome and hyperinsulinemic hypoglycemia. Am J Med Genet A 2005; 139:227-230.

65. Smith VS, Giacoia GP. Hyperinsulinaemic hypoglycaemia in an infant with mosaic trisomy 13. J Med Genet 1985;22:228230.

66. Alkhayyat H, Christesen HB, Steer J, Stewart H, Brusgaard K, Hussain K. Mosaic Turner syndrome and hyperinsulinaemic hypoglycaemia. J Pediatr Endocrinol Metab 2006;19:14511457.

67. Taylor SI, Cama A, Accili D, Barbetti F, Quon MJ, de La Luz Sierra M, Suzuki Y, Roller E, Levy-Toledano R, Wertheimer E, Moncadaj VY, Kadowaki H, Kadowaki T. Mutations in the insulin receptor gene. Endocr Rev 1992;13:566-595.

68. Donohue WL, Uchida I. Leprechaunism: a euphemism for a rare familial disorder. J Pediatr 1954;45:505-519.
69. Böhles H, Sewell AA, Gebhardt B, Reinecke-Lüthge A, Klöppel G, Marquardt T. Hyperinsulinaemic hypoglycaemia-leading symptom in a patient with congenital disorder of glycosylation la (phosphomannomutase deficiency). J Inherit Metab Dis 2001;24:858-862.

70. de Lonlay $P$, Cuer $M$, Vuillaumier-Barrot $S$, Beaune $G$ Castelnau P, Kretz M, Durand G, Saudubray JM, Seta N. Hyperinsulinemic hypoglycemia as a presenting sign in phosphomannose isomerase deficiency: A new manifestation of carbohydrate-deficient glycoprotein syndrome treatable with mannose. J Pediatr 1999;135:379-383.

71. Sun L, Eklund EA, Chung WK, Wang C, Cohen J, Freeze $\mathrm{HH}$. Congenital disorder of glycosylation id presenting with hyperinsulinemic hypoglycemia and islet cell hyperplasia. J Clin Endocrinol Metab 2005;90:4371-4375. Epub 2005 Apr 19

72. Farina MI, Scarani R, Po' $C$, Agosto $C$, Ottonello G, Benini F. Congenital central hypoventilation syndrome and hypoglycaemia. Acta Paediatr 2012;101:92-96.

73. Levitt Katz LE, Satin-Smith MS, Collett-Solberg P, Thornton PS, Baker L, Stanley CA, Cohen P. Insulin-like growth factor binding protein-1 levels in the diagnosis of hypoglycemia caused by hyperinsulinism. J Pediatr 1997;131:193-199.

74. Finegold DN, Stanley CA, Baker L. Glycemic response to glucagon during fasting hypoglycemia: an aid in the diagnosis of hyperinsulinism. J Pediatr 1980;96:257-259.

75. Treberg JR, Clow KA, Greene KA, Brosnan ME, Brosnan JT.Systemic activation of glutamate dehydrogenase increases renal ammoniagenesis: implications for the hyperinsulinism/ hyperammonemia syndrome. Am J Physiol Endocrinol Metab 2010;298:1219-1225. Epub 2010 Mar 23

76. Cryer PE, Axelrod L, Grossman AB, Heller SR, Montori VM, Seaquist ER, Service FJ; Endocrine Society. Evaluation and management of adult hypoglycemic disorders: an Endocrine Society Clinical Practice Guideline. J Clin Endocrinol Metab 2009;94:709-728. Epub 2008 Dec 16

77. Hardy OT, Hernandez-Pampaloni M, Saffer JR, Suchi M, Ruchelli $E$, Zhuang H, Ganguly A, Freifelder R, Adzick NS, Alavi A,Stanley CA. Diagnosis and localization of focal congenital hyperinsulinism by $18 \mathrm{~F}$-fluorodopa PET scan. J Pediatr 2007;150:140-145.

78. Treglia G, Mirk P, Giordano A, Rufini V. Diagnostic performance of fluorine-18-dihydroxyphenylalanine positron emission tomography in diagnosing and localizing the focal form of congenital hyperinsulinism: a meta-analysis. Pediatr Radiol 2012;42:1372-1379. Epub 2012 Aug 12

79. Otonkoski T, Näntö-Salonen K, Seppänen $M$, Veijola $R$, Huopio H, Hussain K, Tapanainen P, Eskola O, Parkkola R,Ekström K, Guiot Y, Rahier J, Laakso M, Rintala R, Nuutila $P$, Minn $H$. Noninvasive diagnosis of focal hyperinsulinism of infancy with [18F]-DOPA positron emission tomography. Diabetes 2006;55:13-18.

80. Lord K, Dzata E, Snider KE, Gallagher PR, De León DD. Clinical presentation and management of children with diffuse and focal hyperinsulinism: a review of 223 cases. $J$ Clin Endocrinol Metab 2013;98:1786-1789. Epub 2013 Sep 20

81. Cornblath M, Hawdon JM, Williams AF, Aynsley-Green A, Ward-Platt MP, Schwartz R, Kalhan SC. Controversies regarding definition of neonatal hypoglycemia: suggested operational thresholds. Pediatrics 2000;105:1141-1145.

82. Shah P, Demirbilek H, Hussain K. Persistent hyperinsulinaemic hypoglycaemia in infancy. Persistent hyperinsulinaemic hypoglycaemia in infancy. Semin Pediatr Surg 2014;23:76-82. 
83. Mohamed Z, Arya VB, Hussain K. Hyperinsulinaemic hypoglycaemia:genetic mechanisms, diagnosis and management. J Clin Res Pediatr Endocrinol 2012;4:169-181. Epub 2012 Oct 2

84. Arnoux JB, Verkarre V, Saint-Martin C, Montravers F, Brassier A, Valayannopoulos $V$, Brunelle $F$, Fournet JC, Robert JJ,Aigrain Y, Bellanné-Chantelot $C$, de Lonlay P. Congenital hyperinsulinism: current trends in diagnosis and therapy. Orphanet J Rare Dis 2011;6:63.

85. Neylon OM, Moran MM, Pellicano A, Nightingale $M$, O'Connell MA. Successful subcutaneous glucagon use for persistent hypoglycaemia in congenital hyperinsulinism. J Pediatr Endocrinol Metab 2013;26:1157-1161.

86. Goldfine AB, Mun EC, Devine E, Bernier R, Baz-Hecht M, Jones DB, Schneider BE, Holst JJ, Patti ME. Patients with neuroglycopenia after gastric bypass surgery have exaggerated incretin and insulin secretory responses to a mixed meal. J Clin Endocrinol Metab 2007;92:4678-4685. Epub 2007 Sep 25

87. Barthlen W, Mohnike W, Mohnike K. Techniques in pediatric surgery: congenital hyperinsulinism. Horm Res Paediatr 2010;74:438-443. Epub 2010 Nov 24

88. Arya VB, Mohammed Z, Blankenstein O, De Lonlay , $_{\text {, }}$ Hussain K. Hyperinsulinaemic hypoglycaemia. Horm Metab Res 2014;46:157-170. Epub 2014 Feb 20

89. Lord K, De León DD. Monogenic hyperinsulinemic hypoglycemia: current insights into the pathogenesis and management. Int J Pediatr Endocrinol 2013;2013:3.

90. Doyle ME, Egan JM. Pharmacological agents that directly modulate insulin secretion. Pharmacol Rev 2003;55:105-131.

91. Yildizdas D, Erdem S, Küçükosmanoglu O, Yilmaz M, Yüksel B. Pulmonary hypertension, heart failure and neutropenia due to diazoxide therapy. Adv Ther 2008;25:515-519.

92. Yorifuji T, Kawakita R, Hosokawa Y, Fujimaru R, Matsubara K, Aizu K, Suzuki S, Nagasaka H, Nishibori H, Masue M. Efficacy and safety of long-term, continuous subcutaneous octreotide infusion for patients with different subtypes of KATP-channel hyperinsulinism. Clin Endocrinol (Oxf) 2013;78:891-897. Epub 2013 Apr 6

93. Laje P, Halaby L, Adzick NS, Stanley CA. Necrotizing enterocolitis in neonates receiving octreotide for the management of congenital hyperinsulinism. Pediatr Diabetes 2010;11:142-147. Epub 2009 Jun 25

94. Le Quan Sang KH, Arnoux JB, Mamoune A, Saint-Martin C, Bellanné-Chantelot C, Valayannopoulos V, Brassier $A$, Kayirangwa $\mathrm{H}$, Barbier $V_{\text {, B }}$ Broissand $\mathrm{C}$, Fabreguettes JR, Charron B, Thalabard JC, de Lonlay P. Successful treatment of congenital hyperinsulinism with long-acting release octreotide. Eur J Endocrinol 2012;166:333-339. Epub 2011 Nov 2

95. Eichmann D, Hufnagel M, Quick P, Santer R. Treatment of hyperinsulinaemic hypoglycaemia with nifedipine. Eur J Pediatr 1999;158:204-206.

96. Müller D, Zimmering $M$, Roehr CC. Should nifedipine be used to counter low blood sugar levels in children with persistent hyperinsulinaemic hypoglycaemia? Arch Dis Child 2004;89:83-85.

97. Baş F, Darendeliler F, Demirkol D, Bundak R, Saka N, Günöz H. Successful therapy with calcium channel blocker (nifedipine) in persistent neonatal hyperinsulinemic hypoglycemia of infancy. J Pediatr Endocrinol Metab 1999;12:873-878.

98. Lindley KJ, Dunne MJ, Kane C, Shepherd RM, Squires PE, James RF, Johnson PR, Eckhardt S, Wakeling E, Dattani M,Milla PJ, Aynsley-Green A. Ionic control of beta cell function in nesidioblastosis. A possible therapeutic role for calcium channel blockade. Arch Dis Child 1996;74:373-378.

99. Suprasongsin C, Suthutvoravut U, Mahachoklertwattana $P_{\text {, }}$ Preeyasombat C. Combined raw cornstarch and nifedipine as an additional treatment in persistent hyperinsulinemic hypoglycemia of infancy. J Med Assoc Thai 1999;82(Suppl 1):39-42

100. Shanbag P, Pathak A, Vaidya M, Shahid SK. Persistent hyperinsulinemic hypoglycemia of infancy--successful therapy with nifedipine. Indian J Pediatr 2002;69:271-272.

101. Darendeliler F, Fournet JC, Baş F, Junien C, Gross MS, Bundak R, Saka N, Günöz H. ABCC8 (SUR1) and KCNJ11 (KIR6.2) mutations in persistent hyperinsulinemic hypoglycemia of infancy and evaluation of different therapeutic measures. J Pediatr Endocrinol Metab 2002;15:993-1000.

102. Senniappan S, Alexandrescu S, Tatevian N, Shah $P_{1}$ Arya V, Flanagan S, Ellard S, Rampling D, Ashworth M, Brown RE, Hussain K. Sirolimus therapy in infants with severe hyperinsulinemic hypoglycemia. N Engl J Med 2014;370:1131-1137.

103. Alexandrescu S, Tatevian N, Olutoye O, Brown RE. Persistent hyperinsulinemic hypoglycemia of infancy: constitutive activation of the mTOR pathway with associated exocrineislet transdifferentiation and therapeutic implications. Int J Clin Exp Pathol 2010;3:691-705.

104. Calabria AC, Li C, Gallagher PR, Stanley CA, De León DD. GLP-1 receptor antagonist exendin-(9-39) elevates fasting blood glucose levels in congenital hyperinsulinism owing to inactivating mutations in the ATP-sensitive $\mathrm{K}+$ channel. Diabetes 2012;61:2585-2591. Epub 2012 Aug 1

105. Bax KN, van der Zee DC. The laparoscopic approach toward hyperinsulinism in children. Semin Pediatr Surg 2007; 16:245-251

106. Al-Shanafey S, Habib Z, AlNassar S. Laparoscopic vs open pancreatectomy for persistent hyperinsulinemic hypoglycemia of infancy. J Pediatr Surg 2009;44:134-138; discussion 138.

107. Beltrand J, Caquard M, Arnoux JB, Laborde K, Velho G, Verkarre V, Rahier J, Brunelle F, Nihoul-Fékété C, Saudubray JM, Robert JJ, de Lonlay P. Glucose metabolism in 105 children and adolescents after pancreatectomy for congenital hyperinsulinism. Diabetes Care 2012;35:198203. Epub 2011 Dec 21

108. Greene SA, Aynsley-Green A, Soltesz G, Baum JD. Management of secondary diabetes mellitus after total pancreatectomy in infancy. Arch Dis Child 1984;59:356-359.

109. Snider KE, Becker S, Boyajian L, Shyng SL, MacMullen C, Hughes N, Ganapathy K, Bhatti T, Stanley CA, Ganguly A. Genotype and phenotype correlations in 417 children with congenital hyperinsulinism. J Clin Endocrinol Metab 2013;98:355-363. Epub 2012 Dec 28 